\title{
Om velfærdsstatens \\ Politiske økonomi - \\ og den ufuldkomne kritik heraf.*
}

\section{Michael Krätke}

»Socialpolitik sikrer det kapitalistiske produktionsgrundlag..., derved at den sociale fordring imødekommes. Socialpolitik nedbryder gradvist kapitalismen og redder derved den rest, der til enhver tid er tilbage. Dette er socialpolitikkens konservativt-revolutionare dobbeltvasen." Eduard Heimann 1929.

$\gg$ Kapitalismens ... manglende evne ... til at tage højde for sine egne fejltagelser har to vitale konsekvenser. Alle dens forebyggende foranstaltninger synes forhastede og utilstrakkelige ... og fär dens kritikere til at indse, at deres sag er mere magtfuld, end de havde forestillet sig."

Harold Laski 1933.

»Penge, der bruges på at opretholde helbreddet og vitaliteten, åndens og kroppens duelighed hos vore arbejdere, er den bedste investering på markedet.« Lloyd George 1911.

»... al socialpolitik, der ikke opfattes som overgang til socialisme (er) selv dømt til at forblive modsigelsesfuld.«

Max Adler 1927.

\section{Velfærdsstatens ideologi og økonomi.}

I løbet af anden verdenskrig blev det de allieredes primære indenrigspolitiske krigsmål at skabe en velfærdsstat, som for altid skulle gøre ende på nationernes indre sociale krig. Til denne krigs pathos hørte ideen om en velfærdsstat, hvor nød, sygdom og uvidenhed skulle besejres, og hvor et »socialt demokrati« skulle virkeliggøres på grundlag af lige grundrettighe-

* Oversættelse af Michael Krätke 'Zur Politischen Ökonomie des Wohlfahrtsstaates' i Prokla $49 / 1982$. 
der for alle. Denne idé blev et politisk kampbegreb for det ikke-kommunistiske venstre i efterkrigstidens Europa. Dette kampbegreb var og er under mistanke for at være ideologisk. Talen om velfærdsstaten kom under ideologisk mistanke, fordi dette nye slagord i den politiske sprogbrug sammen med dets talrige forskønnende paralleludtryk som »social service state«, »social security state «, »full employment state« osv. var en omskrivning af et epokegørende program, som skulle placere den borgerlige retsstats legitimering på et nyt, bredere grundlag (sml. Kraemer 1966, 13f). Det intellektuelle venstre har da også med forkærlighed kastet sig over »socialstatsideologien « og forsøgt at påvise dens ideologiske karakter.

Socialstatskritikken blev således overvejende udøvet som ideologikritik og rettede sig i første række mod retorikken i den socialdemokratiske propaganda, som allerede da flittigt havde gjort brug af talen om »den sociale stat « eller om »den sociale republik «, før udtrykket »velfærdsstat «blev indkorporeret i de »vestlige demokratiers « officielle politiske sprogbrug.

Selv om den politiske hensigt og adressat for kritikken af socialstatsideologien (-erne) var klar, så var og er der stadig ringe klarhed om kritikobjektet. Nøjere betragtet er det slet ikke så enkelt at finde dén herskende socialstatsteori eller blot socialdemokratiets toneangivende socialstatsteori.

I England er der siden 1909 blevet udviklet en lære om social administration under stærk fabiansk indflydelse. Denne lære er også blevet akademisk institutionaliseret. Men selv her beklager førende repræsentanter for den fabianske skole stadig, at der mangler en toneangivende politisk teori om velfærdsstaten (S. Robson, 1976, 82, 171).

Ikke mærkeligt, at den engelske velfærdsstat ikke - end ikke ifølge selvforståelsen hos den vigtigste politiske arkitekter - er kommet i stand efter en plan, men som en ofte afbrudt serie af pragmatiske enkeltløsninger på specifikke sociale problemer. (Bruce 1972, 13). Dog fandtes der naturligvis »store « og »små« løsninger, socialreformer, som alt efter problemernes karakter blev tillagt forskellig vægt.

Da Labour-partiet kom til regeringsmagten i 1945, var det dets erklærede mål at forvandle Storbritannien til en »velfærdsstat«. Dertil havde partiet et program, der i det væsentligste stemte overens med de forslag, som Beveridge-kommissionen havde udarbejdet under krigen. Som ideologisk oppakning havde det ikke andet end den traditionelle fabianske overbevisning, at der findes »fornuftige « løsninger på sociale problemer, som erkendes af og trænger ind i den offentlige bevidsthed; løsninger som med st $\varnothing$ tte fra alle velvilligt indstillede folk, udstyret med »common sense «, også måtte kunne sættes iværk.

Omfanget af statsliggørelsen, standardiseringen, den positiv-retlige kodificering og professionaliseringen i sådanne kunstigt dannede social- 
institutioner, blev betragtet som detailspørgsmål, som skulle afgøres ud fra deres formålstjenlighed. Som Labour fejlagtigt forklarede, var der på ingen måde planlagt en »week-endrevolution«; Laoburpolitikere betonede uafladeligt kontinuiteten, deres socialreforms binding til den engelske socialpolitiks liberale traditioner. (Hess, 1981)

For den vesttyske venstrefløj, som i efterkrigstiden orienterede sig stærkt efter det engelske forbillede, kom der ikke mere ud af det, end at den blev bekræftet i sin gamle overbevisning om, at det vil være muligt og fornuftigt at institutionalisere normer om »social retfærdighed « i kapitalismen; normer som frem for alt vil virke til fordel for ofrene for den borgerlige dagligdag. Den specielt tysk-ideologiske komponent deri var troen på, at det er den borgerlige retsstat - hvilende på en demokratisk forfatning - som kan og skal bibringe det borgerlige samfund en sådan social moral.

I en artikel fra 1970, som stadig har betydning, forsøgte Müller og Neusüss at udvikle et i den marxistiske tradition diskutabelt, socialvidenskabeligt begreb om den reformistiske arbejderbevægelses statsideologi. (Müller og Neusüss 1970) Da henvisningen til velfærdsstaten siden 50'erne mere og mere har tjent til at frakende Marx' kapitalismekritik enhver aktuel berettigelse, kan man næppe opretholde. denne kritik uden at angribe socialstatsideologien.

Skal endvidere kritikken af den nuværende kapitalisme være politisk virksom, kommer den ikke uden om en socialstatskritik. Begrundelsen herfor er, at der eksisterer en tro på, at det er muligt - måske ikke at undgå - men i al fald at kontrollere de uønskede og utilsigtede sociale følger, som den kapitalistiske produktionsproces har for den enkelte og for store klasser i befolkningen. Denne tro spiller en rolle, som næppe kan overvurderes, såvel for legitimeringen af det kapitalistiske system som for den borgerlige stat. (Narr/Offe 1975, 25f)

Ifølge Müller/Neusüss er omfordelings-illusionen, dvs. forestillingen om, at den borgerlige stat suverænt kan gribe ind i indkomstfordelingen og ændre denne efter forgodtbefindende, selve kernen i reformismens socialstatsillusion.

Som Offe har klarlagt, beror dette på illusioner, som Müller og Neusüss selv nærer om det formentlige indhold i de socialstatsopfattelser, de kritiserer. (Offe 1972, 173) Dertil kommer, at de ganske uden videre sætter de tankefejl, som visse socialvidenskabsfolk efter deres opfattelse laver, lig med de illusioner, som socialdemokratiske politikere ligger under for. Hertil knytter de den ubegrundede formodning, at netop disse illusioner også bestemmer den socialpolitiske hverdagsviden hos store dele af arbejderbefolkningen i de kapitalistiske lande. 
Dette er prekært, fordi de så for det første går fejl af socialvidenskabernes begrebsdannelser, som i det mindste er analytisk tænkte. »Socialstat « eller »social retsstat « er netop også analytiske begreber, hvormed der gøres fors $\varnothing \mathrm{g}$ på at få fat på de ændringer, som den liberal-kapitalistiske borgerlige retsstat har erfaret som følge af sit tiltagende socialpolitiske engagement; et forhold, som Offe allerede har henvist til. (Offe 1972, 174).

For det andet undgår de ikke faren for at sætte lighedstegn mellem de formodede eller virkelige illusioner hos socialvidenskabsfolk eller socialdemokratiske levebrødspolitikere, og de illusioner vedrørende indhold og følger af statslig socialpolitik, som er indeholdt i hverdagsbevidstheden hos socialdemokratiske eller på anden måde reformistisk sindede arbejdere.

Müller og Neusüss' første bommert hænger sammen med, at de næsten udelukkende koncentrerer sig om den borgerlige stats omfordelingsfunktion for at gøre kål på illusionen om en handlingsautonomi hos den borgerlige stat i fordelingssfæren. Men den borgerlige socialstat opfylder, selv ved den egentlige omfordeling, mere end blot en omfordelingsfunktion; hvad den historisk set $\mathrm{g} \varnothing \mathrm{r}$ til forskel fra den liberale rets- og politistat angives kun utilstrækkeligt med termen »omfordeling «. Den griber også regulerende og styrende ind i konkurrencen på arbejdsmarkedet, blander sig kontrollerende og normerende i arbejdsforholdene, og bestemmer slutteligt - som den eneste eller vigtigste udbyder, producent eller organisator af offentlige goder og tjenester - en betragtelig del af dagliglivet for hele den ikkeerhvervsduelige befolkning.

Og følgerne, som disse socialpolitiske statsaktiviteter har for integrationen af lønarbejderen i det borgerlige samfund og for den borgerlige stats legitimering, er næppe mindre betydende end de følger, som disse aktiviteter har for det borgerlige samfunds forskellige lags og klassers absolutte og relative indkomstforhold.

Den anden bommert hænger sammen med, at Müller/Neusüss ikke bruger ideologibegrebet i dets egentlige betydning, men kun som et andet ord for teoretikeres tankefejl og illusioner. Uden tvivl hører imidlertid også ideer, normative detaljer, mangefold illusioner, dagligdags folkefordomme samt en bestemt symbolik og social retfærdighedsretorik til velfærdsstatens realitet.

Men for at vide, for hvem og hvorvidt velfærdsstatens realitet er ideologisk eller hvilke socialstatsideologier, der hævder sig som handlingsorienterende i den velfærdsstatsligt organiserede kapitalismes dagligdag, må man vide, hvordan socialstatens institutioner har ændret arbejderklassens stilling, og hvordan den - indenfor klassens erfaringshorisont - har forbedret den. Jo mere detaljeret man ved det, desto bedre bliver man i 
stand til at indkredse de grupper af arbejderbefolkningen i en kapitalistisk velfærdsstat, som ifølge deres livssituation løber den risiko at bære rundt på socialstatsillusioner, hhv. at hoppe på socialstatsideologier, hvor de møder dem.

\section{Venstrefløjen kritiserer velfærdsstaten. Fra den moraliserende kritik til kritikken af den politiske økonomi.}

Müller/Neusüss' fremstød var alligevel vigtigt, fordi det brød med en gammel tradition for dårlig radikal, moraliserende socialstatskritik på venstrefløjen.

Venstrefløjen har nemlig på den ene side indvendt imod velfærdsstaten, at dens officielle målsætning - i retning af at overvinde nød og social usikkerhed - principielt ikke ville kunne realiseres under kapitalismen. På den anden side har venstrefløjen altid målt dens præstationer i forhold til disse målsætninger og bebrejdet den, at den kun har realiseret dem utilstrækkeligt. (smlg. f.x. IMSF 1976, 365, 374f).

Denne type kritik har bragt marxisterne den anklage på halsen, at de ikke eksplicterede deres egne normer for »socialistisk « eller »proletarisk « socialpolitik (nyere undtagelse: Deacon 1981), og at de nøjedes med empiriske en bloc vurderinger. Bemærkninger, som dem i de indledende citater, og f.eks. Max Adlers påstand om, at den moderne socialstat ikke længere er tilfreds med blot at bekæmpe eller forvalte pauperismen, men har gjort »omsorgen for det kapitalistiske samfund « til sin interesse (Adler 1927, 385), kan virke pinlige, når de kun fører til mere eller mindre kulturkritisk farvede generelle betragtninger om målsætningen for den strukturændring, som velfærdsstaten betyder for det kapitalistiske system. Kapitalismens struktur er nok ændret betydeligt, men dog ikke væsentligt; eller systemets totale karakter forbliver det samme, om end væsentligt modificeret. (Heller 1982, ss, Abendroth 1975, 194f).

Man behøver ikke at undre sig over, at selv velmenende modstandere ganske enkelt slår fast, at marxisterne har begrænset sig til polemik mod velfærdsstatens socialdemokratiske apologeter, og på ingen måde har opfyldt deres egentlige videnskabelige opgave, nemlig at give en detaljeret historisk forklaring på de nye socialpolitiske statsinterventioner og deres langsigtede følger for det kapitalistiske system. (Mishra 1977, 86f; George/Wilding 1976, 103f).

Der kan intet indvendes mod en total systemanalyse af den statslige socialpolitik, hvis man kunne enes om den begrebslige opfattelse af referencesystemet »kapitalisme« (Mishra 1977, 80), så meget desto mere 
som det er en overdrivelse på forhånd at sætte »marxistisk « lig med funktionelle analyser med referencerammen »kapitalisme«. (Furke 1978, 29).

Forudsætningen er dog netop, at man undgår den funktionalistiske blindgyde og de harmoniske verdensbilleder, som pryder den: alt hvad der sker socialpolitisk, er funktionelt nødvendigt for »kapitalismen«, og alt hvad der gælder som funktionelt nødvendigt ved socialpolitiske interventioner i kapitalismen, det vil uvægerligt også ske. (Offe 1975, 81).

De foreliggende fors $\varnothing$ g giver ikke grund til optimisme. Engang blev det fors $\varnothing \mathrm{gt}$ at spille funktionalismen et puds med forsikringen om, at kun de intenderede følger af bevidste politiske handlinger fra »borgerlige « politikeres side skal gælde som funktionelle for kapitalen respektive kapitalismen. (Röder/Guldimann 1978, 32). Hvorfor så overhovedet funktionelle analyser?

Den foreslåede analytiske skelnen mellem diverse »strukturproblemer « $\mathrm{i}$ kapitalismen og denne skelnens frugtbarhed i forhold til unders $\emptyset$ gelsen af de foreliggende socialpolitiske indretninger - herunder egentlig også huller, mangler og blinde pletter - blev andre gange afgjort med en forsikring om, at sammenhængen »som oftest ligger lige for « eller, at de forhåndværende socialpolitiske institutioner »pålideligt og konfliktløst « disker op med de funktionelt nødvendige ydelser. (Lenhardt/Offe 1977, 108, 111).

Glemt var den allerede vundne indsigt, at der »altid har forekommet funktionelle diskrepanser mellem det, som værdiøgningsprocessen kræver, og det som politikken gør«. (Offe 1975, 82)

De forenklede tilløb til en funktionel analyse af den statslige socialpolitik under kapitalismen, som blev foretaget af ikke-specialister, åbnede $\varnothing j$ nene for, at der ikke fandtes en marxistisk forskningstradition i socialpolitik, og af den grund var manglen på teori større end de brugbare ansatser. Der kunne lige så lidt tales om systematisk empirisk socialstatsforskning, som om udviklingen af delteorier, f.eks. en for arbejderbevægelsen brugbar »Teori om socialforsikringen « (Bellermann 1977, 352f, Bellermann 1979, 57f).

De nævnte tilløb mindede marxistiske socialvidenskabsfolk om den kritiske fordring, gennem hvilken de havde distanceret sig fra de individualistiske og funktionalistiske varianter af den herskende lære i socialvidenskaberne; nemlig fordringen om at kunne overvinde disses tænkning i abstrakte modsætninger som »er og bør«, »subjekt og objekt«, »handling og struktur «, osv. (Gough, 1978, 38f) Herved stødte de på Marx’ kritik af den politiske $\varnothing$ konomi. 
Man behøver ikke at stilisere denne til system eller uovertrufne standarder for enhver socialvidenskabelig teoridannelse, for dog deri at ane en frugtbar analyseramme til forklaring af det moderne socialstatsfænomen, som ydermere besad det fortrin for marxistiske specialister i socialpolitik, at være praktisk taget ubrugt. (Gough 1979, 7ff).

\section{Kritikprogrammet. Opsving og fald. Modsigelser og grænser for velfærdsstaten under kapitalismen i dag.}

Det var fortsat ikke beskedenhed, som udmærkede marxistiske videnskabsfolk. For at komme på højde med efterkrigsfænomenet i de vestlige velfærdsstater, benytter de ikke en teori af middellang rækkevidde, som kunne bringe den historiske udvikling i den borgerlige stats interventionsformer ind i en systematisk sammenhæng med den kapitalistiske produktionsforms udvikling.

Forklaringen på den kapitalistiske velfærdsstat som historisk fænomen består efter deres opfattelse blot deri, for det første at placere den i sammenhæng med den kapitalistiske udviklings foreløbig sidste fase, og igen at stille dette således analytisk bestemte kompleks af en »velfærdsstatslig « organiseret kapitalisme ind i en historisk udviklingsrække, som leder fra »førkapitalisme « med den »merkantilistiske « absolutistiske stat, over »højkapitalismen« med den »liberalkapitalistiske« borgerlige retsstat, til en »organiseret « (sen-)kapitalisme med den dertil hørende velfærdsstat. Dette er næppe mindre beskedent, og givet ligeså omfattende som den herskende socialvidenskabelige læres konforme forslag, ifølge hvilket velfærdsstaten skal »forstås som et almindeligt strukturfænomen ved moderniseringen « (Flora e.al. 1977, 707).

Resultaterne falder forskelligt ud, alt efter hvilket analytisk begreb om »kapitalistisk udvikling « - evt. i konkurrence med begrebet »modernisering « - man bruger. Man kan med Offe gå efter det kapitalistiske systems selvdestruktive tendens og nå til en logisk, ikke historisk, række af udløsningsmekanismer, hvori der behandles stadigt mere vidtrækkende problemer på stadigt mere omfattende planer - fra enkeltkapital over totalkapital til samlet socialstruktur. Efter denne argumentationsstrategi er den borgerlige stat som velfærdsstat begyndt på at befatte sig med problemer i det borgerlige samfunds totale struktur, frem for alt med den gennem kapitalismen selv stadigt mere truede integration af lønarbejderen i det borgerlige samfund; følgelig har den også etableret sig på alle tænkelige interventionsplaner, og kan herefter kun udnytte de spillerum, som til enhver tid forekommer. (Offe 1972, Narr/Offe 1975). 
Eller man følger det i forskellige varianter tiltrådte udviklingsskema, ifølge hvilket monopoliseringen forbigående redder kapitalen fra selvskabte vanskeligheder, men hvor den i det lange løb kun kan holdes på ret køl ved hjælp af en stadig mere vidtgående statsintervention. Ganske påfaldende spiller velfærdsstaten slet ingen rolle for de fleste tilhængere af denne tese. Hvad den borgerlige stat gør eller skulle gøre for storkapitalens reproduktion og akkumulation, optager dem så stærkt, at de næsten glemmer, hvad den tillige gør for arbejderklassens hhv. det borgerlige samfunds reproduktion.

Man kunne også følge de stagnationsteoretikere, som ganske enkelt forklarer velfærdsstaten dermed, at den kan bidrage kraftigt til at absorbere det overskud, som er permanent til stede i den udviklede kapitalisme, og at den følgelig kan bidrage til at undgå en overakkumulationskrise. (Gillman 1959, Baran/Sweezy 1968).

Fælles for sådanne ansatser er, at velfærdsstaten opfattes som et institutionaliseret »svar « på det borgerlige samfunds strukturelle og uafviselige problemer. Men begrænsningerne ved sådanne ansatser bliver tydelige, når man holder sig for øje, at og i hvilken udstrækning både den kapitalistiske og den borgerlige velfærdsstats udvikling falder forskelligt ud i de forskellige lande, og ovenikøbet gør det uafhængigt af deres kapitalistiske »udviklingsgrad «.

Efter hundre år med statslig socialpolitik (regnet fra den tyske kejsers bekendtgørelse i 1881) er der således fortsat lande med sammenlignelig storindustri og sammenligneligt industrielt proletariat, hvoraf nogen har og nogen ikke har socialforsikring; der findes socialforsikringer - fra de mest vidtgående til meget beskedent statsligt subventionerede og kontrollerede; der er endnu i dag »fattige « og »rige «socialstater - målt på omfang og niveau for deres sociale ydelser - på samme kapitalistiske udviklingstrin; der findes »rige « socialstater med høj grad af centralisering og ensartethed i deres sociale ydelser og ligeså rige socialstater med enorm decentralisering og uensartethed i de sociale ydelser; der er lande på samme kapitalistiske udviklingstrin, hvor de fleste sociale ydelser produceres og fordeles fuldstændigt eller for den langt overvejende del af staten, og der er lande, hvor betragtelige dele af de sociale ydelser i sundheds-, uddannelses- og boligsektoren produceres af private kapitalistiske foretagender til et mere eller mindre betalingsdygtigt publikum. I alle disse tilfælde består marxisternes standardråd i en henvisning til de omskiftelige begivenheder i den historiske klassekamp.

Det ville være tåbeligt at bestride værdien af sådanne historiske forklaringer. Vore socialpolitiske institutioners nuværende former kan for en 
stor del kun gøres forståelige ud fra tidligere tiders interesse- og konfliktniveauer. (Rusche 1933, 69f). Men vanskeligheden består netop deri, at »klassekampene«, som skal levere fortolkningsrammen for den historiske udvikling i de enkelte kapitalistiske velfærdsstater, selv forandres vedvarende gennem opbygningen af socialstatslige institutioner. Klassekampen, som raser mellem det borgerlige samfunds store sociale klasser, får gennem velfærdsstaten nyt indhold, nyt terrain, delvist også nye fronter, nye kampformer og delvist også nye resultater. En lønkamp, der udspiller sig i socialstaten, er f.eks. også en kamp om og tillige en kamp i socialforsikringens institutioner (Saville 1957, Thompson 1958).

Der er ikke vundet meget for socialstatskritikken med de talrige og omfattende karakteriseringer af den moderne velfærdsstat som en statstype, der - idet den står mellem den liberal-kapitalistiske natvægterstat og den socialistiske stat - er staten for en kapitalisme, der er bundet og civiliseret gennem statsindgreb. Det forekommer mig mere fornuftigt, at lade spørgsmålet om den historiske oprindelse og det mere vidtrækkende spørgsmål om den historiske plads, som velfærdsstaten indtager i kapitalismens historie, stå ubesvaret og foreløbig koncentrere sig om de mulige analytiske begrebsdannelser i den marxistiske tradition. Hertil er det nødvendigt at indlade sig på en foreløbig, empirisk generaliserende »arbejdsdefinition« på en velfærdsstat.

Er man - uden krav på forestillinger om en bedre socialstat - kommet til en forståelse om, hvilke statsinterventioner man vil lade gælde som empirisk mindstestandard for en velfærdsstat i den nuværende kapitalisme, så kan man dernæst gå i gang med at prøve, om hhv. hvor langt denne velfærdsstat lader sig begribe med de traditionelle kategorier fra kritikken af den politiske $\varnothing$ konomi.

Det forventes dermed ikke, at socialstatskritikken skal præsentere det normative modstykke (en slags demokratisk-socialistisk »socialstatsmodel«) til den herskende model. (sml. Hartwich 1970, 359, 361f).

I stedet for fortsatte beklagelser over den bestående velfærdsstat må det forlanges af en marxistisk socialstatskritik, at den ikke kun kan bekræfte, men også analytisk begrunde en kapitalistisk velfærdsstats begrænsning, skrøbelighed og indre modsigelsesfuldhed.

En påvisning af hvor og hvordan en kapitalistisk velfærdsstat undergraver sig selv i overensstemmelse med sin egen udviklingslogik - hvis sammenhæng med »kapitallogikken« netop bør undersøges - lader sig naturligvis bruge politisk forskelligt. Men uden sådanne påvisninger bliver socialisterne stående ved et forsvar for det bestående, hvormed store dele af arbejderklassen identificerer sig, imod alle nedbrydningsfors $\emptyset \mathrm{g}$ fra 
højre, og ved den faktiske st $\varnothing$ tte til de socialdemokratiske opbygningsforsøg efter logikken at »mere af det samme til flere mennesker er bedre end mindre af det til færre $\ll$.

En borgerlig stat kan kaldes en velfærdsstat, såsnart den ikke længere blot lover og garanterer ro og orden, ret og retssikkerhed, men tager sig af sine borgeres »velfærd «, det mere eller mindre gode hverdagsliv; ikke blot for udvalgte grupper, men i princippet for alle borgere.

Vi interesserer os i den forbindelse ligeså lidt for graden af kodificering af disse interventioner, der måske forekommer i form af en liste over »sociale grundrettigheder « $\mathrm{i}$ forfatningen, som for den faktiske betydning af normer om social retfærdighed, som kan bestemme statens handlinger.

En stat kan siges at være en borgerlig rets- og ledelsesstat, hvis den ud fra sin form kun orienterer sig mod rationelt erkendbare »interesser « og deriblandt kun mod sådanne, som kan gøres almene.

Den udvider sig til socialstat, såsnart den giver sine borgere virksomme garantier for deres $\varnothing$ jeblikkelige sociale eksistens, dvs. i reglen indkomstgarantier imod det individuelle fald fra deres sociale klasse, imod deklasseringen - i form af mere eller mindre differentierede socialforsikringer og $\mathrm{i}$ form af en almindelig fattigforsorg.

Den bliver en udvokset velfærdsstat, såsnart den derudover udbyder en række vedvarende offentlige goder og tjenester, hvis benyttelse eller ikke-benyttelse ganske vist ikke står borgerne frit for, men som reguleres politisk og i stor udstrækning uafhængigt af deres individuelle betalingsevne.

I en velfærdsstat kan gennemsnitsborgeren $\mathrm{i}$ almindelighed forvente et offentligt opdragelses- og uddannelsesvæsen, et offentligt sundhedsvæsen, offentlige sanitære installationer, et offentligt samfærdselsvæsen, en offentlig boligforsyning, offentlige fritidsanlæg og en kortere eller længere række specialiserede offentlige hjælpe- og forsorgstjenester. (Briggs 1961, 228, Gillman 1965, 214). En fuldbeskæftigelsesgaranti er ikke nødvendig; der kan forekomme kapitalistiske velfærdsstater uden »keynsiansk $\varnothing$ konomisk politik.

Når den borgerlige stat på den beskrevne måde griber ind i de private kræfters spil i det kapitalistiske samfund med ret, penge og offentlige goder, ændrer den dette spil og forandrer derved samtidig sin egen natur. Den borgerlige stat har jo altid ført socialpolitik. Fra at føre fattigforsorgspolitik har den udfoldet sig til at føre »arbejderpolitik « (Gerstenberger 1976, Köhler 1977), og er til sidst i efterkrigstidens prosperitetsperiode nået til at føre almen velfærdspolitik. 
Den borgerlige stat har med udgangspunkt i fattigpolitiet overtaget stadig flere og stadig mere vidtrækkende »reproduktionsfunktioner « og er nu, som udvokset velfærdsstat, ikke blot den vigtigste, formidlende agent for lønarbejderklassens reproduktion næst efter kapitalen selv, men er tillige den vigtigste agent for reproduktionen af hele det borgerlige samfund, der må bruge den som beskyttelse mod de destruktive tendenser i den kapitalistiske produktionsmåde.

\section{Nogle forsøg på begrebsdannelser.}

De første marxister, som behandlede de velfærdsstatslige tendenser, forsøgte at fortolke disse som »socialisering «: socialisering af indkomster, frem for alt lønnen, og socialisering af forbrug og forbrugsmidler, sammenfattet som socialisering af den variable kapital. I denne talemåde (Renner 1918, 1929) ligger en forudanelse om, at med velfærdsstaten kunne den kapitalistiske produktionsmåde ændre sig så vidt, at den ikke længere ville kunne begribes tilstrækkeligt med de traditionelle kategorier fra kritikken af den politiske $\varnothing$ konomi. Tvivlen har i mellemtiden fæstnet sig (Offe 1972, herimod Hirsch 1980). Ikke desto mindre er der i de senere år kommet i det mindste to alvorlige fors $\emptyset \mathrm{g}$ på at anvende Marx' kapitalismekritik på den udviklede velfærdsstat (Grevet 1976, Gough 1979).

\subsection{Indviklet og uudholdeligt - „vardien af varen arbejdskraft«}

Marx' kapitalismekritik står og falder med arbejdsværditeorien. Kategorien merværdi står og falder med »værdien af varen arbejdskraft, « den centrale kategori i Marx’ lønteori. Marx og de fleste marxister anså denne kategori nødvendig for at kunne analysere udbytningsfænomenet i det kapitalistiske samfund. »Værdien af varen arbejdskraft « er det vigtigste analytiske redskab, som den marxistiske tradition kan tilbyde for at kunne begribe reproduktionen af lønarbejderen som individ. Reproduktionsagenten velfærdsstat agerer imidlertid uden bytte, uden varer, uden markeder; socialforsikringsbidragene er ingen pris, de udbetalte pensioner, sygedagpenge osv. er ingen arbejdsløn, de offentlige sociale foranstaltninger såvel som statens sociale tjenesteydelser er ikke varer, og har følgelig ingen værdi. Hvad kan man så bruge en værditeori til?

Når velfærdsstaten kan modificere værdien af varen arbejdskraft og dermed den regulerende størrelse for lønnen dvs. lønomkostningerne og arbejderbefolkningens betalingsdygtige efterspørgsel, så kan den også influere på merværdiens produktion og realisering og derigennem på kapitalens akkumulation. 
To systematiske huller i Marx' opfattelse af værdien af varen arbejdskraft peget henimod, at hans teori er analytisk åben for en sådan mulighed. Til forskel fra, hvad Marx oprindeligt antog (Rowthorn 1979), er varen arbejdskraft ikke en vare som de $\emptyset$ vrige varer, og dens værdi og pris bestemmes ikke som disses; således er »varenarbejdskraft « og »arbejdsløn« særlige kategorier i den politiske økonomi, ligesom »varen jord « og »jordrente« og »jordpris« er særlige kategorier. Der er kun i Piero Sraffas neorecardianske modelverden, at man kan sætte værdien af varen arbejdskraft lig værdien af de af lønarbejderne konsumerede varer. I Marx' verden går det ikke så simpelt. Dette har det ubehagelige resultat for det $\varnothing$ konomiske modelbyggeri, at langtfra alle værdistørrelser lader sig udtrykke som tekniske produktionskoefficienter.

Det første hul i Marx’ teori består deri, at værdien af varen arbejdskraft, dvs. mængden af samfundsmæssigt arbejde, som er nødvendigt til dens produktion og reproduktion, på ingen måde bestemmes fuldstændigt gennem værdien af andre varer, dvs. gennem den arbejdsmængde, som er nødvendig til produktion og reproduktion af »løngoder«. (Ginsburg 1979, 24). Varen arbejdskraft har den ejendommelighed, at den aldrig kan produceres fuldstændigt ved hjælp af andre varer, thi den er en vare, der som sådan overhovedet ikke produceres med henblik på salg. Dette hænger sammen med dens liv og subjektivitet. Arbejdskraften kan netop som vare ikke adskilles fra dens personlige særtræk - med mindre man gjorde arbejderen selv til vare, altså gjorde ham til slave. Følgelig kan den heller ikke produceres som vare på 3 . hånd, men kan kun produceres af arbejderen selv og af mennesker, som ikke primært står i udbytningsrelationer til ham. Arbejderens arbejde for sig selv, forældres arbejde med deres børn, og familiemedlemmernes arbejde i husholdningen er nødvendigt for at gøre og opretholde et individ arbejdsdygtigt. Dette kan kun i meget begrænset omfang - eller slet ikke - lade sig gøre gennem køb af tjenesteydelser, gennem tyende eller husslaver.

Det arbejde, som enhver arbejdskraftsbesidder i sidste ende må yde til sig selv, for at være og opretholde sig arbejdsdygtig og for i sidste ende på ny at kunne bringe sig til markedet, kan ingen lette ham. Her, hvor det tilsyneladende lukkede kredsl $\varnothing b$ af »kapitalistisk vareproduktion ved hjælp af varer « er brudt, kan en teori om velfærdsstaten tage sit udgangspunkt.

Den samfundsmæssigt nødvendige arbejdstid, som går til produktionen af varen arbejdskraft - og den nødvendige arbejdstid, som går til pro-

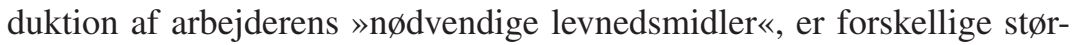
relser.

Selv under den snævre forudsætning, at alt hvad en arbejder behøver $i$ et borgerligt samfund, udelukkende kan opnås som varer, og af arbej- 
deren kun kan tilegnes gennem køb, viser der sig et nyt hul i værdibestemmelsen af varen arbejdskraft. Thi for at kunne bestemme denne lønregulerende værdistørrelse er det ikke tilstrækkeligt at kende de arbejdstider, som under de til enhver tid givne produktionsbetingelser er nødvendige for at producere og reproducere en enhed af de konsumgoder, som på et givet tidspunkt er produceret som varer; det må også bestemmes, hvad der til enhver tid er »løngoder «. Ved bestemmelsen af de varearter, som indgår i kredsen af lønarbejderens »nødvendige levnedsmidler «, spiller et historisk-moralsk element ind, som Marx har betonet. Han har ikke udtalt sig videre om, på hvilken måde der i det kapitalistiske samfund er fundet en almengyldig standard for hvilke varer, i hvilke mængder og hvilke respektive kvaliteter en arbejder skulle kunne købe, og hvorledes denne standard har vundet indflydelse og igen er ændret.

Denne del af Marx' værdibestemmelse for varen arbejdskraft udsiger kun, at de moderne frie lønarbejdere, underkastes samfundsmæssige konsumnormer, skønt de som private pengebesiddere er formelt frie og formelt ligestillede med enhver anden køber på varemarkedet.

Deres daglige tilværelse, såvidt som den bestemmes af konsumvarer, ligger under for samfundsmæssige standarder for et godt liv, smukke boliger, fornuftig rekreation - vel at mærke »for arbejdere«.

Køberne af arbejdskraft vil nok trykke dens normalpris, men under kapitalismen har de ikke kunnet ophæve lønarbejdernes formelle konsument-suverænitet, og de er historisk af den borgerlige stat blevet tvunget til at respektere denne, dvs. at udbetale lønarbejderne individuel pengeløn. Derfor blev og bliver den uløselige konflikt mellem dem og lønarbejderne om indholdet af de proletariske konsumnormer udkæmpet via moralsk indflydelse og opdragelse. Denne moralske opdragelse af lønarbejderen følger snart forbilledet af den sparsommelige, flittige og beskedne arbejder, som bringer sig og sin familie beskedent, enkelt men altid ordentligt gennem livet. Og snart - i USA allerede tidligt i 30'erne, i Vesteuropa først i 50'erne - svinger den om til forbilledet af den velhavende, kreditværdige arbejder, for hvem selv livslang gældsstiftelse ikke er nogen skam, når han står overfor besiddelsen af standardiserede velstandsgoder såsom eget hus og egen bil (Aglietta 1979).

Netop her, hvor forbindelsen mellem den værdi, som den enkelte arbejders arbejdskraft repræsenterer på arbejdsmarkedet, og værdisummen af de varer, som er »normale « konsumgoder for ham, ikke mere kan bestemmes entydigt gennem tekniske produktionsbetingelser i konsumgodesektoren, ligger et andet udgangspunkt for teorien om velfærdsstaten. 
Nogle af de varer, som en lønarbejder i et kapitalistisk samfund behøver for at kunne leve, har ganske vist priser, men ingen regulerende værdistørrelse. Sådan er det, for at tage det vigtigste tilfælde, med »varen bolig «. Huslejen er et konglomerat af ægte omkostninger, grundskyld, kapitalforrentning og -amortisation. Lønarbejderen lever i en vareverden, som kun delvist beherskes af værdistørrelser, og vigtige områder, som f.eks. lejeboligsektoren beherskes ikke af værdier. For lønarbejderens overleven betyder bestemmelsen af den gennemsnitlige arbejdsløn gennem en således sammensat værdistørrelse en bestandig fare for eksistensen, også selv om han var fuldt beskæftiget og blev betalt i overensstemmelse med sin arbejdskrafts værdi. Her ligger et nyt udgangspunkt for en teori om velfærdsstaten.

Værdien af varen arbejdskraft kan slutteligt ikke stemme overens med lønarbejderens virkelige reproduktionsomkostninger, fordi denne regulerende værdistørrelse kun refererer til udbytningsakten, hvori brugsværdien af den menneskelige arbejdskraft sammen med retten til at bruge den overdrages til kapitalisten for et bestemt tidsrum.

I det kapitalistiske lønsystem har den individuelle arbejdskraftkøber udelukkende en tidsmæssigt begrænset forpligtelse overfor individuelle arbejdskraftsælgere. Han har ikke nogen forpligtelse overfor de mennesker, som den individuelle arbejder lever sammen med udenfor virksomheden, og såsnart den tidsmæssigt begrænsede købskontrakt er udløbet, ophører den også overfor denne individuelle arbejder.

Naturligvis er de omkostninger, som livet som privatmand i det borgerlige samfunds vareverden påtvinger den enkelte lønarbejder forskellig, alt efter hvordan og med hvem han lever sammen, hvor mange børn han har, hvor stor hans $\varnothing$ vrige familie er osv., og naturligvis ophører livet i vareverdenen ikke med at påtvinge arbejderen omkostninger, såsnart han - uanset af hvilken grund - ikke kan sælge sin arbejdskraft.

Disse to reproduktionsproblemer for lønarbejderen i det borgerlige samfund, nemlig problemet med familielønnen og problemet med livslønnen, peger ikke på huller i værdibestemmelsen af varen arbejdskraft. Det er uden videre muligt og ret enkelt at sammenskrive de af Marx gjorte antydninger om arbejdskraftens »opdragelses- og uddannelsesomkostninger « - at opstille en værdisum for de varer, som arbejderfamilien beh $\varnothing$ ver til daglig, og at udvide denne sum til summen af alle varer, som en arbejder, der ikke kan sælge sin arbejdskraft, må konsumere for at kunne opretholde hhv. genfremstille dens brugsværdi og dermed dens salgbarhed. Dette betyder blot, at det berømte »historisk-moralske« element må udvides med en normering af hhv. en »normal arbejderfamilie« og en 
proletarisk levestandard for gamle, syge, invalide eller slet og ret arbejdsløse arbejdere.

Begge disse reproduktionsproblemer er systemproblemer ved lønsystemet. Der er derfor ingen immanente løsninger, som alment ville kunne bruges af enhver tilfældig lønarbejder og arbejdsgiver.

Den individuelle arbejdsgiver kan ikke af sig selv og i en situation med fri konkurrence med alle andre private arbejdsgivere udbetale løn, differentieret efter familiestørrelsen. I den frie konkurrence på arbejdsmarkedet slår ungkarlen familiefaderen, og forsørgeren af en lille familie slår forsørgeren af en stor familie. På den anden side har det kapitalistiske system og alle arbejdsgivere qua repræsentanter for kapitaler brug for arbejdstagerbørn. Hvis alle voksne lønarbejdere trykkes ned på ungkarlens lønniveau, må konkurrencen på arbejdsmarkedet enten frigives fuldstændigt også for kvinder og børn, eller også vil arbejderbefolkningens reproduktion forringes, gøres langsommere og formodentlig også dårligere. Der findes indenfor det rene lønsystem kun alternativet mellem enten at alle, eller at kun en del af arbejderbefolkningen gøres til paupere, og begge alternativer bliver til byrder på den til enhver tid opvoksende arbejdergeneration.

En privat arbejdsgiver, som forholder sig rationel i den kapitalistiske produktionsmåde, vil ikke betale for en arbejder, hvis arbejdskraft han ikke kan bruge. Thi i det rene kapitalistiske system hersker der organiseret forpligtelses- og ansvarsfrihed.

En hvilken som helst tilfældig individuel lønarbejder kan indgå og ophæve en arbejdskontrakt med en hvilken som helst tilfældig individuel arbejdsgiver; ethvert beskæftigelsesforhold er opsigeligt og gælder jo alligevel kun for en bestemt tid.

Lønarbejderen selv, og ikke hans til enhver tid midlertidige »arbejdsgiver«, er alene ansvarlig for sit liv og sin overleven. Mens han på den ene side er fri til at skifte arbejdsgiver, og altså ikke kender en personlig »husbond «, så finder han sig på den anden side »herreløs « overladt til sig selv, altså uden krav på eller garantier fra nogen som helst fra »herreklassen «, i samme øjeblik han ikke længere kan sælge sin arbejdskraft.

Tilstedeværelsen af usolgt, og for længere eller kortere perioder usælgelig eller delvist usælgelig arbejdskraft, er nødvendig for det kapitalistiske system som industriel reservearmé, også selv om de ikke kan sørge for deres eget underholde De sørger for et stedse nærværende udbud på arbejdsmarkedet, de sikrer arbejdsgiverne chancen for at kunne vælge mellem mange arbejdskraftssælgere, de kan udfylde huller i arbejdskraft- 
udbuddet med kort varsel - her hænger de to nævnte systemproblemer sammen - og de sørger for et vedvarende konkurrencetryk mellem lønarbejderne. Men det kan de kun, hvis de ikke sulter, hvis deres arbejdskraft beholder sin brugsværdi, hhv. hvis og for så vidt de sættes i stand til igen at reparere deres arbejdskraft eller ændre den således, at de får en ny salgschance.

Arbejdsgiverne betaler ikke for underhold til arbejdere, hvis arbejdskraft de måske selv kunne få brug for, men som deres konkurrenter sandsynligvis mindst lige så godt kunne bruge.

De, der tilhører den industrielle reservearmé, kan som besiddelsesløse proletarer ikke selv sørge for deres underhold. En teori om velfærdsstaten må også knytte an til disse to systemproblemer.

Dermed kan der skitseres et analytisk begreb om velfærdsstaten, som slutter sig til Marx' kapitalismekritik. En borgerlig stat, som udfylder de nævnte huller, eller som på eget ansvar bearbejder de nævnte reproduktionsproblemer for lønarbejderne, kunne kaldes en velfærdsstat. Altså en stat, som for det første overtager i det mindste en del af det samfundsnødvendige arbejde med produktion og reproduktion af arbejdskraft, (et arbejde som i den rene kapitalisme er gratisarbejde), organiserer det og dermed delvist forvandler det til betalt arbejde; en stat, som for det andet blander sig aktivt - som en art moralsk opdragelsesanstalt - i de underste klassers moralske økonomi, og løfter i det mindste en del af de konsumnormer, som gælder for arbejdere i det borgerlige samfund, op til formelt-almene statsborgerlige normer, og således legitimerer dem. En stat, som for det tredie forsøger at slå bro over kløften mellem pris- og værdisystemet dér, hvor den bliver eksistenstruende for lønarbejderbefolkningen. Og en stat, som last not least - beskæftiger sig med problemerne med familieløn og løn i betydningen leveomkostninger, altså beskæftiger sig med de systemnødvendige diskreapanser mellem de virkelige reproduktionsomkostninger og værdien af varen arbejdskraft, og - uanset med hvilket resultat - hjælper denne omkostningsdel frem til samfundsmæssig anerkendelse som en art sociale omkostninger ved lønarbejdet, normerer disse omkostninger og organiserer deres dækning og fordeling. Det sidste ville være tilstrækkeligt til at definere det analytiske begreb »socialstat«. Det mere vidtrækkende analytiske begreb »velfærdsstat kan først skitseres med hele listen.

\subsection{Socialløn eller indirekte løn.}

Allerede under første verdenskrig beklagede den østrigske højre»marxist « Karl Renner, at »vi marxister « endnu ikke havde analyseret den $»$ socialisering af arbejdslønnen $\ll$, som den borgerlige stat havde ind- 
ledt, og som måtte føre til de nye komplementære fænomener »socialløn « og »kollektivløn« for lønarbejderne (Renner 1918, 47).

I mellemtiden har der bredt sig den antagelse i den vesteuropæiske arbejderbevægelse, at de fleste statslige sociale ydelser på en eller anden måde hører ind under løn, eller i hvert fald under lønkamp; ideen om socialløn har vundet indpas (Wilson 1977, 73. Gough 1975, 75f).

Udtrykket »socialløn« er dog blot en falsk analogi. Selv rent monetære ydelser har intet som helst at gøre med udvekslingen mellem køber og sælger af arbejdskraft; de er ensidige pengeoverførsler. Følgelig kan de heller ikke opfattes som ækvivalenter. Dette skal ikke tages som en nedvurdering af den journalistiske eller agitatoriske værdi af udtrykket. Men en politisk nyttig metafor er stadigvæk ikke et analytisk begreb (Wilson 1980, 82 mod Gough 1979).

Når det drejer sig om at analysere de kapitalistiske velfærdsstater i fuld udfoldelse, vil marxistiske $\varnothing$ konomer først og fremmest interessere sig for, hvem der skal betale de statslige sociale ydelser. Hvem påhviler det at bære velfærdsstatens byrder, den besiddende klasse eller arbejderklassen? Omfordeles der gennem de velfærdsstatslige interventioner kun løndele blandt den lønafhængige befolkning, eller indskrænkes den herskende klasses private rigdom derved? Eller udtrykt i den marxske kapitalismekritiks analytiske sprogbrug: Kan velfærdsstaten øve indflydelse på skillelinien mellem »værdien af varen arbejdskraft « og »merværdien«? Hvis ja, bliver merværdien reduceret til fordel for en stigende værdi af varen arbejdskraft, eller kan det også gå den anden vej? Kort sagt, hvorledes ændrer velfærdsstaten det centrale udbytningsforhold under kapitalismen, mindsker eller øger den udbytningen af lønarbejderen?

Den type problemstillinger forudsætter antagelsen, at velfærdsstatens »ydelser« overvejende kommer ikke-kapitalister til gode. Betydningen af disse problemstillinger bliver klar, når man holder sig for øje de mulige slutninger, som kan drages af de alternative svar.

Hvis byrderne ved de sociale ydelser skal bæres af merværdien, så har vi i det mindste opdaget én central modsætning i velfærdsstatens $\varnothing$ konomiske eksistens: Den sikrer og forbedrer reproduktionen af varen arbejdskraft dér, hvor det er systemnødvendigt og hvor kapitalen ikke selv formår det. Det er nødvendigt for kapitalen og gunstigt for lønarbejderne. Men idet og for så vidt som den tager vare på denne reproduktionsfunktion, undgår den ikke samtidig at skade kapitalen økonomisk. En sådan løbende konflikt tvinger den borgerlige velfærdsstat til en fortsat splittet adfærd. Den må etablere sig som den instans, som i forhold til de fleste af lønarbejdernes reproduktionsproblemer er »kompetent « og i stand til no- 
genlunde heldigt at håndtere dem. Således vinder den materiel legitimering og aflaster arbejdsgiverne på lønfronten. Men samtidig og i samme omfang må den dæmpe de krav, de forhåbninger og forventninger om social sikkerhed og materiel velfærd, som den vækker hos lønarbejderbefolkningen; den må skrue disse krav ned eller skuffe dem, fordi deres indfrielse vil belaste kapitalen.

Hvis det derimod er værdien af varen arbejdskraft, som fuldstændigt må bære byrderne ved de sociale ydelser, og denne værdistørrelse trods statsinterventionen forbliver den samme, så er den borgerlige stat qua velfærdsstat hjælpeløst fanget i interne konflikter mellem forskellige grupper og lag af lønarbejdere, mellem aktive og ikkeaktive, mellem unge og gamle, bedre og dårligere kvalificerede lønarbejdere, mellem en stabil »kerne« og ustabile »marginalgrupper« osv. Den omfordeling, som påtvinges af staten, og som holder sig nøjagtigt indenfor grænserne af værdien af varen arbejdskraft, gør den til en yderligere udbytter for nogle, især de bedrestillede arbejdergrupper og provokerer fortløbende fordelingskonflikter i arbejderklassen. For helt at udnytte det $\varnothing$ jeblikkelige $\varnothing$ konomiske spillerum må den borgerlige stat på den ene side gå helt ud til klassegrænserne, og altså søge at gennemtvinge en art solidaritet mellem alle lønafhængige; men på den anden side kan og tør den ikke - som garant for det borgerlige samfund - sætte en stopper for de af privatinteresser bestemte gruppekampe inden for arbejderklassen.

Der findes indtil nu kun få brugbare tilløb til løsning af disse indviklede problemer, der har så vide konsekvenser. Der findes tre mulige løsningsvarianter, som imidlertid dels forkyndes dogmatisk, dels forsvares med et yderst beskedent opbud af argumenter.

Den første løsning lyder: Alle statslige sociale ydelser er - værdimæssigt betragtet - blot fradrag i merværdien, og socialstaten må uvægerligt trykke merværdien og følgelig hæmme akkumulationen. At socialstaten kun skulle være en ren og skær merværdispiser, hindrer ikke fortalerne for denne overbevisning i, ofte i samme åndedrag, at opstille den politiske fordring, at det ville være mest bekvemt, hvis »bourgeoisiet« bar samtlige sociale byrder (Linde 1931, 16, 17. Gillman 1959, 20. Fine/Harris 1976, 107).

Den anden løsning siger, at velfærdsstaten forhøjer værdien af varen arbejdskraft og idet den vedvarende ændrer denne værdibestemmelse, først derigennem effektivt beskærer merværdien. Dette skulle være muligt, fordi velfærdsstaten således skaffer nye, yderligere livsfornødenheder for lønarbejderne samfundsmæssig anerkendelse som 
»nødvendige livsforn $\varnothing$ denheder «, og derved udvide cirklen af »nødvendige livsforn $\varnothing$ denheder « for arbejdere. (Weigle 1960, 47f, Bellerman 1977, 367)

Velfærdsstaten normerer givetvis lønarbejdernes fornødenheder; formodentlig vækker den også krav hos arbejderbefolkningen eller hjælper disse krav frem til almindelig anerkendelse (v. Ferber 1967, 47). Men om denne delvise ændring, eller om man vil, berigelse af arbejderklassens behovsstruktur, bevirker at værdistørrelsen forstået som nødvendigt anerkendte levnedsmidler for arbejderklassen, nødvendigvis må stige, det kan man betvivle, netop fordi disse behov vedrører traditionelle mangel- og nødsituationer (alder, børnerigdom, sygdom, arbejdsudygtighed).

Den tredie mulige løsning består $\mathrm{i}$ at foretage en anden inddeling indenfor den - $\varnothing \varnothing v$ rigt uændrede - st $\varnothing$ rrelse af værdien af varen arbejdskraft, som merværdien forbliver uberørt af. De sociale ydelser forklares ganske enkelt som »lønbestanddele «, og som sådanne omdøbes de kort og godt til bestanddele af værdien af varen arbejdskraft.

Efter Renners forbillede får man en række skematiske inddelinger af arbejdslønnen i »individualløn/socialløn« (Renner 1929, 62f), »direkte/indirekte løn« (Delaunay 1971, 63ff. Gouverneur 1978, 79f), »pengeløn/socialløn«(SOST 1980, 15, 17), eller man spises af med den påstand, at lønnen takket være socialstaten skulle tilføres nogle nye bestanddele, netop de statslige sociale ydelser (Bellerman 1979, 72. Tittel 1967, 95f).

Den slags klassifikationer motiveres med, at der ved siden af det »individuelle « varekonsum indenfor den private arbejderhusholdnings rammer, med velfærdsstaten er opstået en ny konsumsfære, i hvilken der ikke mere konsumeres individuelt og ikke konsumeres varer. Men ingen stiller sig det nærliggende spørgsmål, hvilken betydning den »værdibestemmelse «, som refererer til arbejdskraften som vare, nu har i disse offentlige politiserede og statsligt administrerede sfærer.

Den teoretiske opgave og dens vanskeligheder i forbindelse med velfærdsstaten kan belyses ved hjælp af eksempler på nyere forsøg på at analysere de ændringer, som sker i reproduktionsmåderne for arbejderklassen i kapitalistiske lande gennem velfærdsstaten (Grevet 1976, Capian 1979, Gough 1979). Generelt sagt ligger dilemmaet med velfærdsstaten deri, at den bearbejder det borgerlige samfunds reproduktionsproblemer på en måde, som uvægerligt trækker nye og større reproduktionsproblemer efter sig.

Det borgerlige samfunds løsninger på reproduktionsproblemerne for varen arbejdskraft er af en sådan karakter, at de ikke blot gør lønarbej- 
dereksistensen mindre risikabel, men at de tillige igen og igen delvist løser lønarbejderne fra deres afhængighed af markedet, dvs. midlertidigt ophæver tvangen til at købe og at sælge sig. Spørgsmålet er, hvordan den kapitalistiske produktionsmåde, der bygger på værdien, udvikler sig i det lange løb, når reproduktionen af varen arbejdskraft, der danner den centrale betingelse for både kapitalens og den borgerlige stats reproduktion, for en betydelig del ikke mere bestemmes af værdien. Spørgsmålet er ikke blot, om værdistørrelsen bliver større eller mindre; gennem velfærdsstaten sættes der også spørgsmålstegn ved selve værdibestemmelsen såvel for varen arbejdskraft som for adskillige løngoder.

Ian Gough kommer med sit modige fremstød straks ud i modsigende udsagn: Kapitalakkumulationen indskrænkes gennem velfærdsstaten, og den indskrænkes ikke; fremmes snarere. Han svinger mellem disse to mulige standpunkter: sociallønnen, som hos ham er statens monetære social ydelser, må betales ud af profitten, og hindrer altså kapitalakkumulationen; eller sociallønnen bestrides ud af værdien af varen arbejdskraft, og hindrer altså ikke akkumulationen (Gough 1979, 14, 102, 117. Wilson 1980, 83). Denne vaklen mellem uforenelige positioner er ikke noget tilfælde, og ingen personlig svaghed.

Den første grund til Goughs usikkerhed ligger i, at han for at analysere de statslige sociale udgifter nødtvungent griber tilbage til O'-Connors forsøg på en marxistisk analyse af statsudgifterne under kapitalismen (O’Connor 1973, Gough 1975). Herudfra opløser han de statslige sociale udgifter i »social variabel kapital«, og »sociale omkostninger«, dvs. de må enten være lønomkostningsformindskende og derfor »indirekte produktive « for kapitalen, eller de må bidrage »uproduktivt« til underhold af den til enhver tid ikke-arbejdende del af lønarbejderbefolkningen (Gough 1979, 52f). Gough må imidlertid indrømme, at mange statslige sociale ydelser hører hjemme i begge kategorier. En knivskarp inddeling af socialudgifter i sådanne, som omend ad omveje befordrer merværdiproduktionen, og sådanne, som kun tærer på værdiskabelsen i den vareproducerende privatkapitalistiske sektor, lader sig med andre ord ikke gennemføre. Det overrasker således ikke, at O'Connor roder rundt i det, når han skal fastlægge sine tre typer statsudgifter: social konstant og social variabel kapital samt sociale omkostninger. Han sammenblander slet og ret en mulig funktionel opdeling (i en akkumulations- og en legitimationsfunktion) med en mulig kredsløbsteoretisk opdeling (i statsudgifter, som er omkostningsbesparende for den private kapital og sådanne, som ikke er det).

O'Connor giver de velkendte kategorier fra den herskende finansvidenskab: »social kapital« og »socialt konsum«, en marxistisk nybenæv- 
nelse, men han gør det kun i et inddelingsskema, som mangler enhver kredsløbsanalytisk underbygning. Han opgiver det derfor selv igen til fordel for en inddeling efter opgaveformål, som de til enhver tid stærkest regerende grupper forfølger via beslutninger over det statslige udgiftsbudget (O'Connor 1973, 64, 70,).

Følgelig kan Gough heller ikke slippe for først at undersøge dé statslige sociale udgifter, som han i mangel af bedre må kalde sådant noget som »social variabel kapital«, i lyset af deres funktioner og økonomiske virkninger i den samfundsmæssige totalkapitals reproduktionsproces.

Den anden årsag til Goughs usikkerhed ligger deri, at han søger at udvide det centrale problem, om og hvorledes reproduktionen af arbejderbefolkningen, som formidles af den borgerlige velfærdsstat, fortsat bestemmes af »værdien af varen arbejdskraft«, idet han forsøger at føre dette problem tilbage til værdibestemmelsen af varen arbejdskraft.

Om dette begreb må man, i al fald hvad angår Marx, sige, at han ikke kan have glemt velfærdsstaten, selv om det står tilbage at udarbejde ansatspunkter for de velfærdsstatslige indgreb.

Gough vender sig med rette mod det ortodokst-marxistiske dogme, at alle skatter ja tilmed alle sociale udgifter, uanset formen, skulle være merværdifradrag. (Gough 1975, herimod Fine/Harris 1976, Gough 1979)

Han opstiller to modstridende påstande mod dette dogme: nemlig for det første at alle sociale ydelser, pengeoverførsler og offentlige goder, som indgår i den beskæftigede lønarbejders konsum, indgår i værdien af varen arbejdskraft. Heraf følger, at det underhold, som staten skaffer den del af arbejderbefolkningen, som til enhver tid ikke er beskæftiget, ikke skal regnes med til værdien af varen arbejdskraft. Samtidig påstår han for det andet, at samtlige statslige sociale ydelser, altså også dem, som den ikke-beskæftigede arbejderbefolkning konsumerer, må financieres, produceres og fordeles indenfor grænserne af værdien af varen arbejdskraft (Gough 1979, 114, 117, 120).

Gough kan ikke bestemme sig for, hvilken af konflikterne mellem kapitalister og ikke-beskæftigede arbejdere, eller mellem beskæftigede og ikke-beskæftigede lønarbejdere han skal udnævne til velfærdsstatens centrale konflikt. I stedet for at forfølge problemet, hvordan den til enhver tid ubeskæftigede arbejderbefolkning ved hjælp af den borgerlige stat trods alt kan holdes på et proletarisk leveniveau og i en form for lønafhængighed, og hvorledes dette indvirker på levestandarden for de beskæftigede arbejdere, som takket være statshjælpen avancerer fra »potentielle paupere « til potentielle »socialstatsklienter «, så tilbyder han et diagram over det velfærdsstatslige kredsl $\varnothing$ b, som naturligvis kun angiver, hvad der allerede er indeholdt $\mathrm{i}$ hans forudsætninger (Gough 1979, 114 ff). For- 
udsætningen er, at kapitalisterne hverken ved financiering eller tildeling eller konsum af de statslige sociale ydelser spiller nogen som helst rolle. Alt hvad der i en periode fordeles via statslige indkomstoverførsler og konsumeres via sociale ydelser, betaler lønarbejderne selv via skatter og socialforsikringsbidrag.

Det antydes noget beskedent i skemaet, at de skatter og socialforsikringsbidrag, som lønarbejderne har betalt, ikke udelukkende tjener til financiering af statslige sociale opgaver, men derudover forbliver harmonien ubrudt.

Selv dette skema er imidlertid et fremskridt i forhold til den marxistiske tradition med at bide sig fast i udgangsproblemet og spørgsmålet om, i hvilken udstrækning hvilke skatter og socialforsikringsbidrag kan væltes over på andre. Overvæltningschancen vokser med den relative magt på markedet. Om man stiller sig tilfreds med anråbelsen af klassekampen (Peschke 1962, 261), eller om man anstiller betragtninger over mere eller mindre fuldstændige fænomenbeskrivelser (Tittel 1967, Fuhrke 1976), så forbliver både værdibestemmelsen af varen arbejdskraft og af merværdien uberørt heraf.

Derimod påvirkes denne værdibestemmelse meget vel af de pengeoverførsler, som beskæftigede og ubeskæftigede lønarbejdere får tildelt fra staten, og af de offentlige goder og tjenester, hvis brugsværdi tilbydes hhv. påtvinges dem udenfor markedscirkulationen.

Patrice Grevet og Alain Capian har vovet et skridt videre på dette punkt. Når lønsystemet formelt ændres gennem velfærdsstatens indgriben, idet den enkle og udvidede lønarbejderreproduktion for en stor del eller på mange områder udelukkende formidles gennem ikkekapitalistiske ikke-vareforhold, hvad bliver der så af værdien, som kun kan bestemme arbejderens liv for så vidt, som han holdes indespærret i det bestandige kredsløb mellem arbejdsmarked, private virksomheder, konsumgodemarked og privathusholdning (Grevet 1976, 174ff. Capian 1979, 74f, 76f)? Deres svar er: Værdien deler sig op i en politisk bestemt konsumnorm for de ubeskæftigede og en politisk bestemt arbejdsnorm for de beskæftigede lønarbejdere. Sagt på en anden måde, så normerer velfærdsstaten, hvad der er »nødvendige eksistensmidler « for den ikke-arbejdende befolkning, og hvad der i overensstemmelse hermed er nødvendig arbejdstid for de arbejdende proletarer.

Værdibestemmelsen af varen arbejdskraft er altid normativ, idet den er afhængig af den gældende levestandard, der opfattes som normal for en masse privatpersoner; i den rene kapitalisme virker denne norm gennem den kvantitative indskrænkning af det frie konsumvalg, som 
den normale pengeløn overlader den »frie arbejder«. Spørgsmålet er, om indholdet af denne norm også ændres gennem normeringens anden form, den »politiske anerkendelse«, og hvorledes. (Grevet 1976, 52. Capian 1979, 72).

Normen får et betydeligt udvidet indhold, når velfærdsstaten anerkender dét, som ikke kan finde anerkendelse på det frie arbejdsmarked nemlig behovene hos dem, som ikke kan værdisættes, de gamle, syge, invalide og overflødige arbejdere. Men indholdet ændres for så vidt ikke, fordi denne anerkendelse fortsat kun kan bevæge sig på det proletariske leveniveau, som den borgerlige stat selv har normeret. Følger man Grevet's og Capian's argumentation, så ændres der intet ved arbejderklassens behovsstruktur gennem velfærdsstaten, hvor det drejer sig om indkomstoverførsler.

Velfærdsstaten skaber en officiel differentiering i lønarbejdernes status ved siden af arbejdsmarkedets differentiering. De immanente skranker for, hvad den kan anerkende som legitim og nødvendig, ligger i selve lønarbejderstatusen. Når salgstvangen forbigående suspenderes for nogle lønarbejdere, så må i det mindste den anden side af lønafhængigheden bibeholdes, nemlig tvangen til at købe alt livsnødvendigt som varer på markedet. Det går fortrinligt ved hjælp af en indkomstnorm, som er dannet ud fra »værdien af varen arbejdskraft«, altså en pengesum som er afmålt efter den gennemsnitlige prissum af de varemængder, som i en begrænset periode er nødvendig for at eksistere som individ.

For den ubeskæftigede del af arbejderbefolkningen ville det derfor være fuldstændig ligegyldigt, om den således normerede overførselsindkomst, som åbner dem en periodisk adgang til varemarkedet, nu stammer fra fradrag i merværdien eller fra værdien af arbejdskraften blandt de beskæftigede.

\subsection{Socialt eller kollektivt konsum.}

Sålænge socialstaten uddeler respektive omfordeler pengeindkomster, spiller den en art formidlerrolle ved reintegrationen af private personer i den borgerlige vareverden. Hvor differentieret end staten behandler de forskellige »sociale tilfælde «, bestræber den sig på at holde eller bringe deres borgerlige privatautonomi på fode. Klienterne skal igen lande på varemarkedet som pengebesiddere, hvor de selv afgør, hvilke af de udbudte varer, de vil købe til privatforbrug.

Men derudover producerer og fordeler den borgerlige stat goder og tjenester, hvis brugsværdi bestemmes af politiske afgørelser over, hvad der er statsborgerne til gavn og glæde. Sådanne brugsværdier antager i 
reglen ikke vareform. Hvis lønarbejderne kan bruge dem, kan de indgå i deres reproduktion.

Ved en analyse af velfærdsstaten byder sådanne statsligt producerede goder og tjenester på et indviklet problem. De er ikke gaver fra himlen, men er produktet af samfundsmæssigt arbejde, og de kan derfor næppe - som ikke-varer - forstås ud fra værdikategorierne. Deres produktions-, driftsog Øvrige omkostninger dækkes af skatteprovenuet.

Følgelig er der ikke længere nogen entydig sammenhæng mellem hvor meget enhver bruger af sådanne goder og tjenester, og bidraget til deres samfundsmæssige produktions- og reproduktionsomkostninger. For den enkelte eller for hele grupper af private kan - alt efter deres position i skattekampen - sådanne goder og tjenester helt igennem være (gratis) gaver fra samfundet. Hvem der derved udbytter hvem, er vanskeligt at fastslå. Altså også hvem der i sidste ende bærer byrderne ved den sædvanlige reproduktion af varen arbejdskraft, der i velfærdsstaten sker ved hjælp af ikke-varer, som staten snart stiller til rådighed for sine borgere, snart påtvinger dem.

Den herskende lære i finansvidenskaben betegner sådanne ikke-varer som »offentlige goder «, og forklarer deres tilstedeværelse midt i den kapitalistiske produktionsmåde med en mere eller mindre fuldstændigt katalog over mulige »markedssvigt «.

Det marxistiske bidrag til belysning af disse fænomener har hidtil bestået i, hvor det var muligt, at sætte markedssvigten i sammenhæng med en mangel på faktisk eller forventet profitabilitet for private arbejdsgivere. En sådan argumentation lader sig også følge i teorien om velfærdsstaten. Den skal vise hvilke løngoder - dvs. hvilke af de goder og tjenester, som på et givet tidspunkt anses for nødvendige til den enkle og udvidede reproduktion af arbejderbefolkningen i et kapitalistisk land - der ikke vil kunne produceres af privatkapitalistiske vareproducenter hhv. ikke vil kunne erhverves af private lønarbejdere.

Marxistiske økonomer har haft for vane på arbejderklassens vegne at tilegne sig de offentlige goder ved at bruge generelle vendinger af typen »konsumsocialisering « eller et »kollektivt konsum« (Renner 1918, 46. Aglietta 1979, 165). Offentlige goder kan i reglen ikke tilegnes privat, og derfor er deres brugsværdi også vanskelig at konsumere privat. Det betyder dog langtfra, at de altid er blevet konsumeret kollektivt eller endog »fælles«, og det betyder endnu mindre, at offentlige konsumgoder altid er blevet konsumeret af proletariske kollektiver. Hvor der overhovedet bliver 
gjort forsøg på at begrunde et offentligt godes kollektive konsumkarakter, overtages den herskende læres dogme, at der findes goder, som qua deres natur er udelelige, dvs. at de ikke kan splittes op i sådanne portioner, så de kan bruges af enkeltindivider (Prétecielle 1975, 288f. SOST 1980).

Trods al retorik om samfundsmæssiggørelse viser kapitalismen sig dog at være meget resistent overfor »sagens natur«. For hvert eksempel på »kollektivgoder « som teater, svømmehal, skole, sygehus osv. osv., kan det påvises, at det også udmærket kan forekomme i kapitalistisk vareform.

Samtidig har de marxistiske $\varnothing$ konomer bestandig gentaget, at offentlige goder altid har en slags »komparativ omkostningsfordel « for kapitalisterne (således også Gough 1979). Disse skulle slippe billigere fra det, når deres lønarbejdere må betale skat og socialafgifter i stedet for prisen på visse nødvendige konsumgoder. Derfor vil det altid være mere profitabelt for den samfundsmæssige total-kapital at overlade en række af løngoderne til statslig produktion, og trække sig tilbage fra dele af løngodesektoren til fordel for socialstaten. Udvidelsen af det »sociale « konsum med offentlige løngoder vil altid være mere fordelagtig end en brugsværdimæssig lige udvidelse af lønarbejdernes private varekonsum (Rowthorn 1979, 211f).

Denne analogi med den relative merværdiproduktion kan naturligvis kun holde, når man for det første foretager en »medregning « af betalte lønskatter og konsumerede dele af bestemte offentlige goder, altså antager, at lønarbejderne kun kan konsumere en mængde af offentlige goder, der svarer til det de har betalt i skat; og når man for det andet uden videre indrømmer staten en principiel produktivitetsfordel overfor alle mulige private producenter.

\section{Den ubehagelige »socialstatskrise«.}

I den nuværende krise betragtes velfærdsstaten næsten generelt som ophav snarere end offer. Den opfattes som en del af problemet, ikke som løsningen på det. Dens egen specifikke krise i den almene krise opfattes som selvforskyldt. Socialstatens krise opfattes også af marxister som en »finanskrise «, undertiden i en fundamental version, hvori socialstaten fremstilles som en merværdi- og ressourceæder, som er direkte eksistenstruende for kapitalen. Undertiden fremstilles den i en mere afdæmpet version, hvor hovedargumentet er, at statsfinanserne ikke kan beherskes, eller at de truer med at glide ud af kontrol.

Grundstrukturen i argumentationen er simpel og kan udmærket forenes med de mest forskellige analytiske udsagn om fordelingen af byrder 
og fordele i velfærdsstaten: den vanskeliggør en virksom udrensning under krisen, fordi den samtidig beskytter lønarbejderne mod krisens følger. Og den uddyber krisen, fordi den organiserer denne beskyttelse af de mest truede proletariske kriseofre for en stor del på kapitalens bekostning.

At velfærdsstaten ikke kan unddrage sig en cyklisk krise, er selvindlysende. Når man påstår, at de statslige sociale udgifter altid belaster merværdien, så virker socialstaten kriseskærpende gennem sin blotte eksistens, og endda uden en egen strukturel krise - dels fordi den kraftigt indsnævrer finansieringsspillerummet for privat akkumulation ved at trække skat ud af merværdien og kapital ud af kapitalmarkedet, dels fordi den bidrager til

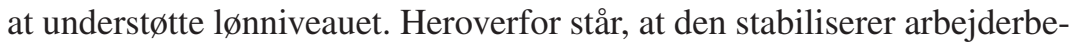
folkningens konsumefterspørgsel eller dog i hvert fald kan forsinke faldet i deres købekraft.

Velfærdsstaten er overhovedet ikke konstrueret med henblik på forekomsten af kriser, men har at gøre med lønarbejdernes vedvarende cyklusuafhængige reproduktionsproblemer. Til trods herfor konfronteres den i den cykliske krise nødvendigvis med en mængde kortfristede, påtrængende reproduktionsproblemer, som den hverken kan afvise eller udskyde eller endog bearbejde adækvat.

Udviklingen af velfærdsstaten har gjort den statslige formidling af privat produktion og reproduktion af arbejdskraft til alment accepteret »normaltilstand «. Velfærdsstaten har historisk set en legitimeringsbasis uden sammenligning, netop fordi den tillader enhver af sine borgere et institutionaliseret krav på hjælp i nødstilfælde, og ydermere fordi den i stor udstrækning har absorberet selvhjælpsinitiativerne, frem for alt fra arbejderbefolkningen. Den kan ikke komme uden om denne forventningsstruktur. Den kan heller ikke tilfredsstille den. Thi i den cykliske krise vokser den pengeklemme, som socialstaten geråder i, til krise. Det sker fordi den på den ene side taber i kapacitet overfor de voksende problemer, som den officielt og ifølge sin egen definition er forpligtet overfor, og fordi den på den anden side i det mindste forbigående må afgive kompetence til fordel for et rent instrumentelt mål: opretholdelsen af sin egen handlingsduelighed. Det bliver forbigående vigtigere at opretholde det sociale sikringssystem, som socialstaten organiserer, end at garantere dette systems ydelser over for enkelte kriseofre.

Skønt den kan vinde tid og penge, mister den legitimitet. Kravene til staten om også under krisen at være handlingsdygtig, og det vil sige også at være betalingsdygtig i fremtiden, kan kun opfyldes, hvis den opgiver noget af sin handlingskompetence, og altså selv iscenesætter en »statslig 
svigten «, som koster den autoritet. Men frem for alt koster disse ufrivillige selvbegrænsninger velfærdsstaten støtte fra sine klienter fra arbejderklassen og skaffer den modstand fra socialsystemets hidtidige bidragsmodtagere. Den tager den gentagne gange bekræftede ret til »social sikkerhed « fra nogle og gør dem til ofre for en krise, der fremtræder som statens krise; andre beskærer den et udbytningsområde uden at kunne bøde på dette gennem parallelle byrder, som den pålægger arbejderklassen. Det forekommer også at være det egentlige indhold i den nuværende »socialstatskrise «: at den strukturelle ændring af det borgerlige samfund er skredet så langt frem, at »point of no return« til den uorganiserede kapitalisme forlængst er overskredet.

Oversættelse: Jens Lærke Nielsen.

\section{Litteratur}

Abendroth 1975: Wolfgang, Abenroth, Der demokratische und soziale Rechtsstaat als politischer Auftrag, in: ders., Arbeiterklasse, Staat und Verfassung, Frankfurt a.M./Köln 1975, S. 179-201

Adler 1927: Max Adler, Über den Begriff der Sozialpolitik, in: Der Kampf, 20 Bd. (1927), Heft 8, S. 379-386

Aglietta 1979: Michel: Aglietta, A Theory of Capitalist Regulation. The US Experience, London 1979 (1976)

Baran/Sweezy 1968: Paul A. Baran/Paul M. Sweezy, Monopolkapital. Ein Essay über die amerikanische Wirtschafts- und Gesellschaftsordnung, Frunkfurt a.M. 1968 
Bellermann 1977: Martin Bellermann, Der Sozialstaat der BRD. Krise und Grenzen, in: Volkard Brandes u.a. (Hrsg.), Handbuch 5. Staat, Frankfurt a.M. 1977, S. 352-370

Bellermann 1979: Martin Bellermann, Expansion und Stagnation. Zu Begriff und Entwicklung der Sozialversicherung in der Bundesrepublik, in: Gesellschaft, Bd. 12, Frankfurt a.M. 1979, S. $56-100$

Briggs 1961: Asa Briggs, The Welfare State in Historical Perspective, in: Archives Européennes de Sociologie, II (1961), p. 221-258

Bruce 1972: Maurice Bruce, The Coming of the Welfare State, London 1972 (1961)

Capian 1979: Alain Capian, Réflexions sur les déterminants de la socialisation du capital variable, in: Issues, no 4, Paris 1979, S. 68-82

Castells 1977: Manuel Castells. Die kapitalistische Stadt. Ökonomie und Politik der Stadtenwicklung, Hamburg-Westberlin 1977

Deacon 1981: Bob Deacon, Social Administration, Social Policy and Socialism, in: Critical Social Policy, Volume 1, No 1, Summer 1981, p. 43-66

Delaunay 1971: Jean-Claude Delaunay, Essai marxiste sur la Comptabilité Nationale, Paris 1971

v Ferber 1967: Christian von Ferber, Sozialpolitik in der Wohlstandsgesellschaft, Hamburg 1967

Fine/Harris 1976: Ben Fine/Lawrence Harris, State Expenditure in Advanced Capitalism: A Critique, in: New Left Review, No 98, p. 97-112

Flora u.a. 1977: Peter Flora/Jens Alber/Jürgen Kohl, Zur Entwicklung der westeuropäischen Wohlfahrtsstaaten, in: Politische Vierteljahresschrift, 18. Jg., Dez. 1977, H. 4, S. 707-772

Fuhrke 1976: Monika Fuhrke, Staatliche Sozialpolitik. Eine Untersuchung zur Entwicklung des Systems der sozialen Sicherheit im Kapitalismus, Offenbach 1976

Fuhrke 1978: Monika Fuhrke, Sozialpolitische Reformen oder Austeritypolitik in der Krise? Zur Kritik neuerer Theorieansätze in der Sozialpolitik, in: Prokla 33, 8. Jg. (1978), Heft 4, 3-35

George/Wilding 1976: Vie George/Paul Wilding, Ideology and Social Welfare, London 1976

Gerstenberger 1976: Heide Gerstenberger, Staatliche Sozialpolitik als Instrument gesellschaftlicher Kontrolle, in: Kritische Justiz, Heft 4/1976, S. 394-406

Gillman 1959: Joseph M. Gillman, Wohlfahrsstaat und Kapitalismus. Der Überfluss bleibt unbewältigt, in: Periodikum für wissenschaftlichen Sozialismus, Heft 12, München 1959, S. $17-36$

Gillman 1968: Joseph Gillman, Prosperität in der Krise, Frankfurt a.M. 1968

Ginsburg 1979: Norman Ginsburg, Class, Capital and Social Policy, London 1979

Gough 1975: Ian Gough, State Expediture in Advanced Capitalism, in: New Left Review, No 92 , p. $53-89$

Gough 1978: Ian Gough, Theories of the Welfare State: A Critique, in: International Journal of Health Services, Vol. 8, (1978), No 1, pp. 27-40

Gough 1979: Ian Gough, The Political Economy of the Welfare State, London 1979

Gouverneur 1978: Jacques Gouverneur, Eléments d'Economie Politique Marciste, Bruxelles 1978

Grevet 1976: Patrice Grevet, Besoins populaires et financement publique, Paris 1976

Hartwich 1970: Hans-Hermann Hartwich, Sozialstaatspostulat und gesellschaftlicher Status quo, Köln/Opladen 1970

Heller 1982: Agnes Heller, Trotzdem: Sozialistische Zielsetzung?, in: Wiener Tagebuch, 2/1982, S. $19-22$

Hess 1981: Jürgen C. Hess, The Social Policy of the Attlee Government, in: W.J. Mommsen (edit.), The Emergence of the Welfare State in Britain and Germany. 1850 - 1850, London 1981, p. 296-314

Hirsch 1980: Joachim Hirsch, Der Sicherheitsstaat, Das Modell Deutschland, seine Krise und die neuen sozialen Bewegungen, Frankfurt a.M. 1980

IMSF 1976: Institut für Marxistische Studien und Forschungen (Hrsg.), Wirtschaftskrise und Wirtschaftspolitik, Frankfurt a.M. 1976 
Jones/Novak 1980: Chris Jones/Tony Novak, The State and Social Policy, in: Philip Corrigan (edit.), Capitalism, State Formation and Marxist Theory, London-Melbourne-New York 1980, pp. 143-170

Köhler 1977: Ernst Köhler, Arme und Irre. Die liberale Fürsorgepolitik des Bürgertums, Berlin 1977

Kraemer 1966: P.E. Kraemer, The Societal State, Meppel 1966

Linde 1931: H. Linde, Lohntheorie und Lohnpolitik der Sozialdemokratie, Wien/Berlin 1931

Mishra 1977: Ramesh Mishra, Society and Sozial Policy. Theoretical Perspectives of Welfare, London 1977

Müller/Neusüss 1970: Wolfgang Müller/Christel Neusüss, Die Sozialstaatsillusion und der Widerspruch von Lohnarbeit und Kapital, in: Sozialistische Politik, 2. Jg. (1970), Heft 6/7, S. 4-67

O’Connor 1973: James O'Connor, The Fiscal Crisis of the State, London/New York 1973

Offe 1972: Claus Offe, Wortmeldung - Eine Gegenpolemik, in: ders., Strukturprobleme des kapitalistischen Staates, Frankfurt a.M., S. 169-188

Offe 1975: Claus Offe, Anmerkungen zum Aufsatz »Intensivierung der Arbeit und staatliche Sozialpolitik « von Fritz Böhle und Dieter Sauer, in: Leviathan, Heft 1/1975, S. 79-83

Offe/Narr 1975: Claus Offe/Wolf-Dieter Narr, Einleitung (Spätkapitalismus - Wohlfahrtsstaat - Massenloyalität), in: dies. (Hrsg.), Wohlfahrtsstaat und Massenloyalität, Köln 1975, S. 9-46

Offe/Lenhardt 1977: Claus Offe/Gero Lenhardt, Staatstheorie und Sozialpolitik. PolitischSoziologische Erklärungsansätze für Funktionen und Innovationsprozesse der Sozialpolitik, in: Christian von Ferber/Franz-Xaver Kaufmann (Hrsg.), Soziologie und Sozialpolitik, Sonderheft 19 der Kölner Zeitschrift für Sozialpsychologie, Opladen 1977, S. 98-127

Peschke 1962: Paul Peschke, Geschicte der deutschen Sozialversicherung. Der Kampf der unterdrückten Klassen um soziale Sicherung, Berlin (DDR) 1962

Préteceille 1975: Edmond Préteceille, Besoins sociaux et socialisation de la consommation, in: La Pensée, Spécial Sociologie »Besoins et consommation«, no 180, avril 1975, p. 22-60

Renner 1918: Karl Renner, Marxismus, Krieg und Internationale, Stuttgart 1918

Renner 1929: Karl Renner, Wege der Verwirklichung, Berlin 1929

Robson 1976: William A. Robson, Welfare State and Welfare Society. Illusion and Reality, London 1976

Rödel/Guldimann 1978: Ulrich Rödel/Tim Guldimann, Sozialpolitik als soziale Kontrolle, i: Starnberger Studien 2, Tim Guldimann u.a., Sozialpolitik als soziale Kontrolle, Frankfurt a.M., S. 11-55

Rowthorn 1979: Bob Rowthorn, Marx' Theory of Wages, trykt i: ders., Capitalism, Conflict and Inflation. Essays in Political Economy, London 1980, p. 182-230

Rusche 1933: Georg Rusche, Arbeitsmarkt und Strafvollzug. Gedanken zur Soziologie der Strafjustiz, i: Zeitschrift für Sozialforschung, Jg. 2 (1933), Heft 1, S. 63-230

Saville 1957: John Saville, The Welfare State: An Historical Approach, i: New Reasoner, No 3, $1957 / 58$, S. 5-20

SOST 1980: Sozialistische Studentengruppen (SOST), Sozialsstaatskritik von links? Arbeit, Gesundheit, Renten, Soziale Sicherheit. Alternativen zur Sozialpolitik, Hamburg 1980

Thompson 1958: Dorothy Thompson, Reply to John Saville, i: The New Reasoner, No 4, 1958, S. $125-127$

Tittel 1967: Gottfried Tittel, Die Legende von der Bonner Sozialstatlichkeit, Berlin (DDR) 1967

Weigle 1960: Klaus Weigle, Die Krankenversicherung im Streit der Klassen, i: Periodikum für Wissenschaftlichen Sozialismus, Heft 17, München 1960, S. 41-56

Wilson 1977: Elizabeth Wilson, Women and the Welfare State, London 1977

Wilson 1980: Elizabeth Wilson, Marxism and the Welfare State, i: New Left Review, No 122, London 1980, pp. 79-89 


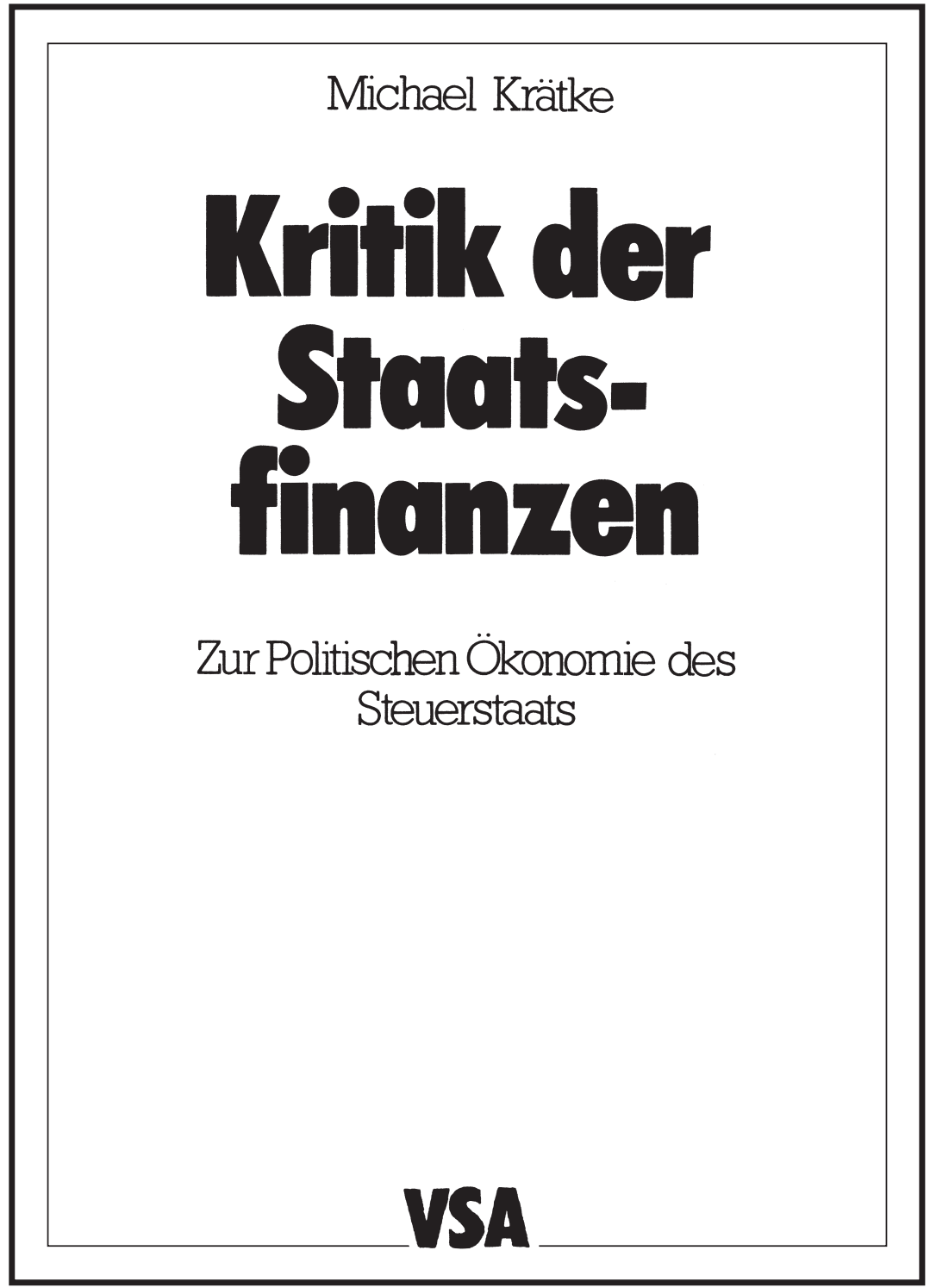

Pris dkr. 135,-

Bestil hos Kurasje bogimport

Krystalgade 16, 1172 København K

Giro 7166044

Skriv efter vort katalog over udenlandske bøger 